\title{
Endothelial Cells Modulate Renin Secretion from Isolated Mouse Juxtaglomerular Cells
}

\author{
Armin Kurtz," Brigitte Kaissling," Rudi Busse," and Wolfgang Baierl \\ *Institut für Physiologie der Universität Regensburg, Germany; ${ }^{\ddagger}$ Anatomisches Institut der Universität Zürich, Switzerland; \\ Institut für angewandte Physiologie und Balneologie, Universität Freiburg, Germany; \\ and "Physiologisches Institut der Universität Zürich, Switzerland
}

\begin{abstract}
Utilizing cocultures of mouse renal juxtaglomerular cells with bovine microvascular endothelial cells, we have examined whether endothelial cells exert direct influence on renin secretion from renal juxtaglomerular cells.

In the presence of endothelial cells both spontaneous and forskolin $(10 \mu \mathrm{M})$ or isoproterenol $(10 \mu \mathrm{M})$ stimulated renin release were markedly attenuated. The stimulatory effect of the calmodulin antagonist calmidazolium $(10 \mu \mathrm{M})$ on renin secretion was not altered by endothelial cells, whereas the stimulatory effect of ethylisopropylamiloride $(50 \mu \mathrm{M})$ an inhibitor of sodium-proton exchange was enhanced in the presence of endothelial cells. Indomethacin $(10 \mu M)$ and $N^{G}$-monomethyl- $l$-arginine (NMMA) (1 mM) used to inhibit cyclooxygenase activity and production of endothelium-derived relaxing factor (EDRF) decreased spontaneous renin release in the presence of endothelial cells only, but had no effect on forskolin stimulated renin secretion. Endothelin $(1 \mu M)$ inhibited cAMP stimulated renin release both in the absence and in the presence of endothelial cells. ATP (10 $\mu \mathrm{M})$ which acts on both endothelial and juxtaglomerular cells via purinergic $P_{2}$ receptors inhibited cAMP stimulated renin release only in the absence but not in the presence of endothelial cells. This modulatory effect of endothelial cells was no altered by indomethacin nor by NMMA.

Taken together, our findings provide first evidence for a local control function of the endothelium on cAMP stimulated renin secretion from renal juxtaglomerular cells, which could in part be mediated by endothelin. (J. Clin. Invest. 1991. 88:1147-1154.) Key words: cyclic AMP • ATP • endothelin • EDRF • prostacyclin
\end{abstract}

\section{Introduction}

During the last decade it has been recognized that the main function of vascular smooth muscle cells (VSMC), ${ }^{1}$ namely,

Address correspondence to Dr. Armin Kurtz, Physiologisches Institut, Universităt Regensburg, Postfach 397, D-8400 Regensburg, Germany. 1991.

Received for publication 22 March 1991 and in revised form 14 June

1. Abbreviations used in this paper: DIC, differential interference contrast; EC, endothelial cell; EDRF, endothelium-derived relaxing factor; JG, juxtaglomerular; $\mathbf{P G I}_{2}$, prostacyclin; VSMC, vascular smooth muscle cell.

J. Clin. Invest.

(c) The American Society for Clinical Investigation, Inc.

$0021-9738 / 91 / 10 / 1147 / 08 \$ 2.00$

Volume 88, October 1991, 1147-1154 contraction, is essentially modulated by the endothelium (1). It is thought that endothelial cells exert their effects on VSMC by the release of locally produced and released factors, some of which have a very short biological half-life. Such factors released by the endothelium comprise prostacyclin $\left(\mathrm{PGI}_{2}\right)$ and endothelium-derived relaxing factor (EDRF) both leading to relaxation of VSMC, and endothelin, a very potent contractor of VSMC (1). This physiologically relevant influence of the endothelium on the contractility of VSMC arises the question of whether endothelial cells may also influence other functions of VSMC, such as the secretory behavior of renal juxtaglomerular (JG) cells which are metaplastically transformed VSMC (2, 3). They are located in the walls of afferent arterioles just adjacent to the glomeruli. The JG cells produce, store, and secrete the protease renin in a regulated fashion.

Although it has been fairly established that renin secretion is influenced by the blood pressure, sympathetic nerves, a number of hormones, and by the sodium chloride intake, the local and cellular control of renin secretion is not yet clear (4). In particular, it is unknown whether endothelial cells in contact with JG cells have some mediating or modulating effect on renin secretion controlled by the physiological parameters mentioned above. Recent findings, namely that prostacyclin (5), which is the major cyclooxygenase product of arachidonic acid in endothelial cells, EDRF (6) and endothelin (7-10) significantly influence renin secretion in vitro, suggest that endothelial cells in fact could play a relevant role in the regulation of renin secretion. A controlled study about direct effects of endothelial cells on renin secretion from renal juxtaglomerular cells has to our knowledge not yet been undertaken. It appeared reasonable therefore to examine if endothelial cells can exert a direct influence on the secretory function of JG cells. To this end we used cocultures of mouse renal cortical cells enriched in juxtaglomerular cells (11) with microvascular endothelial cells isolated from bovine adrenal glands (12). Those fenestrated capillary endothelial cells (EC) are similar to the endothelial cells in the juxtaglomerular region.

With these cocultures we intended to firstly address the following questions. How do EC influence spontaneous and stimulated renin release from JG cells? What is the role of locally released endothelial autacoids, such as prostacyclin, EDRF, and endothelin in the control of renin secretion? How does a physiological factor that activates both EC and JG cells via the same signalling mechanism influence renin secretion in the absence and in the presence of EC?

Our findings show that EC exert an inhibitory effect on certain routes of regulated renin secretion. Moreover, locally released endothelial autacoids were found modulate renin release, and finally our results suggest that the equipment of EC and JG cells with the same type of receptor could provide a physiological principle for fine tuning of renin secretion. 


\section{Methods}

Isolation of mouse juxtaglomerular cells. Mouse JG cells were isolated according to the method described previously (11). For one preparation the kidneys of eight male C57B16 mice (age 4-6 wk) were used. The animals were sacrificed by cervical dislocation, the kidneys were extirpated, decapsulated, and minced with a scalpel blade. The minced tissue was incubated under gentle stirring in buffer $1(130 \mathrm{mM} \mathrm{NaCl}, 5$ $\mathrm{mM} \mathrm{KCl}, 2 \mathrm{mM} \mathrm{CaCl}$, $10 \mathrm{mM}$ glucose, $20 \mathrm{mM}$ sucrose, $10 \mathrm{mM}$ Tris- $\mathrm{HCl}, \mathrm{pH} 7.4$ ) supplemented with $0.25 \%$ trypsin and $0.1 \%$ collagenase at $37^{\circ} \mathrm{C}$ for $70 \mathrm{~min}$. The material was then sifted over a $22-\mu \mathrm{m}$ screen and single cells passing the screen were collected and washed with buffer 1 (at $500 \mathrm{~g}$ for $10 \mathrm{~min}$ ). The washed single cells (final volume $6 \mathrm{ml}$ ) were mixed with $120 \mathrm{ml}$ of $30 \%$ isoosmotic Percoll solution, equally distributed into four centrifugation cups and centrifuged at $27,000 \mathrm{~g}$ in an SS34 rotor and Sorvall RC5C centrifuge (Sorvall Instruments, Newton, CT) for $25 \mathrm{~min}$.

Four apparent bands were obtained with the gradients. Specific renin activity of band III cells $(1.075 \mathrm{~g} / \mathrm{ml})$ was twofold and 64-fold higher than that of band II and band I cells, respectively. Band III cells were used for primary culture.

Primary culture of isolated mouse juxtaglomerular cells. Band III cells were freed from Percoll by washing two times with $50 \mathrm{ml}$ of buffer 1. The cells were then suspended in $12 \mathrm{ml}$ of culture medium (RPMI 1640 supplemented with $0.66 \mathrm{U} / \mathrm{ml}$ insulin, $100 \mathrm{U} / \mathrm{ml}$ penicillin, 100 $\mu \mathrm{g} / \mathrm{ml}$ streptomycin, and $2 \%$ dialyzed fetal bovine serum) and distributed in 500- $\mu$ l portions into 24-well plates. The cultures were incubated at $37^{\circ} \mathrm{C}$ in a humidified atmosphere containing $5 \% \mathrm{CO}_{2}$ in air.

Culture of bovine capillary endothelial cells. Cloned capillary endothelial cells from bovine adrenal glands (12) were kindly provided by Dr. R. Montesano (Geneva, Switzerland), who obtained them from Dr. M. Furie (New York, NY). Cells were grown under standard conditions in $\alpha$-MEM supplemented with $10 \%$ FBS. Confluent cultures were passaged at a ratio of 1:4. For cocultures endothelial cells were seeded in 24-well plates and grown for $3 \mathrm{~d}$. On the fourth day the culture medium was removed and renal cortical cell suspensions prepared as described above were seeded at the same number as in the absence of endothelial cells in $500 \mu \mathrm{l}$ of their culture medium (see above). $24 \mathrm{~h}$ later the culture medium together with the nonattached cells was removed, $500 \mu \mathrm{l}$ of fresh medium was added and the experiments were started.

Culture of human hepatoma cells (Hep-G2). Hep-G2 cells were obtained from the American Type Culture Collection (Rockville, MD). They were kept in $\alpha$-MEM supplemented with $10 \%$ FBS. For the cocultures with juxtaglomerular cells the Hep-G2 cells were grown in 24-well plates under the same conditions as described above for endothelial cells.

Preparation of cellular extracts. For determination of intracellular renin activity cellular extracts were prepared. At the end of the incubation experiments, the culture medium was thoroughly removed. Then, $0.5 \mathrm{ml}$ of PBS supplemented with $0.1 \%$ triton X-100 were added to the cells kept on a shaker for $20 \mathrm{~min}$ at room temperature. Afterwards the solutions were centrifuged at $2,000 \mathrm{~g}$ for $10 \mathrm{~min}$ and the supernatants were saved at $-20^{\circ} \mathrm{C}$ fot further processing.

Experiments. Experiments on renin secretion were performed between the 20th and 40th hour of primary culture of renal cells. After 20 $h$ of primary culture the culture medium was removed and the cultures were washed once with culture medium. Then fresh and prewarmed culture medium together with the drugs to be tested or their respective solvent controls were added. Renin secretion rates were estimated from the appearance rate of extracellular renin activity. At the end of the incubations also the cells were harvested and renin activity was determined therein.

For a certain experimental condition six wells were used per preparation. Results are expressed as means \pm SEM of $n$ experiments, each experiment representing the mean of six replicate culture wells.

Measurement of renin activity. Renin activity was determined by its ability to generate angiotensin I from the plasma of bilaterally nephrec- tomized rats (13). Angiotensin I was measured by radioimmunoassay (Medipro, Teufen, Switzerland).

Measurement of intracellular calcium in endothelial cells. Fluorescence measurements on single endothelial cells were performed as described by Neher (14). Microvascular endothelial cells grown on glass cover slips were loaded with $2 \mu \mathrm{M}$ fura-AM for 40 min under cell culture conditions. Afterwards the cells were thoroughly rinsed with a standard saline solution (in mmol/liter: $140 \mathrm{NaCl}, 3 \mathrm{KCl}, 2 \mathrm{CaCl}_{2}, 1$ $\mathrm{MgCl}_{2}, 11$ glucose, $10 \mathrm{mM}$ Hepes/ $\mathrm{NaOH}, \mathrm{pH}$ 7.2) and then incubated with this buffer during the fluorescence measurements. Fluorescence was excited alternately by light at 360 and $390 \mathrm{~nm}$ by means of a rotating filter wheel fitted to a slot in the excitation pathway of the microscope. $[\mathrm{Ca}]_{\mathrm{i}}$ was calculated from the fluorescence ratio (15). Application of ATP $(10 \mu \mathrm{M})$ was done by pressure ejection from a pipette as described (16).

Measurement of nitric oxide release from endothelial cells. Release of nitric oxide from endothelial cells was assayed on the basis of the stimulatory effect of NO on the activity of soluble guanylate cyclase (GC). Soluble GC was purified from bovine lung. The activity of the enzyme was determined in test tubes in terms of formation of cyclic $\left[{ }^{32} \mathrm{P}\right]$ GTP. Reactions were carried out in a reaction mixture containing $30 \mathrm{mM}$ triethanolamine- $\mathrm{HCl}$ ( $\mathrm{pH} 7.4$ ), $1 \mathrm{mM}$ reduced glutathione, 4 $\mathrm{mM} \mathrm{MgCl}, 0.1 \mathrm{mM}$ cyclic GMP and $0.1 \mathrm{mg} / \mathrm{ml}$ bovine gamma-globuline (total volume of $0.18 \mathrm{ml}$ ) at $37^{\circ}$ in the presence of $\alpha-\left[{ }^{32} \mathrm{P}\right] \mathrm{GTP}$ $(0.03 \mathrm{mM} ; 0.2 \mu \mathrm{Ci})$ and soluble $\mathrm{GC}(4 \mathrm{mg})$. For the determination of NO in the supernatants of monolayers (24-well plates), samples of $50 \mu \mathrm{l}$ were removed from the bath solution $30 \mathrm{~s}$ before and 60 and $150 \mathrm{~s}$ after addition of ATP $(10 \mu \mathrm{M})$ and quickly transferred to the reaction mixture. Enzymatic formation of cyclic GMP was allowed to proceed for $60 \mathrm{~s}$ and was then stopped by the addition of $450 \mu \mathrm{l}$ sodium carbonate $(120 \mathrm{mM})$. Details of the method have been described elsewhere (17). $N^{G}$-Nitro-l-arginine $(30 \mathrm{M})$ was added to the cells $5 \mathrm{~min}$ before stimulation with ATP.

Measurement of 6-keto-PGF $F_{1 \alpha}$ and cyclic GMP. Measurements of $\mathrm{PGI}_{2}$ release were performed in cells from the same batch grown on 24-well plates (Falcon Labware, Heidelberg, Germany). Each well was filled with $200 \mu \mathrm{l}$ Hepes/Tyrode's solution. ATP $(10 \mu \mathrm{M})$ was added and $60 \mathrm{~s}$ later the volume covering the cells was completely removed and assayed for $\mathrm{PGI}_{2}$ by a specific radioimmunoassay for 6-keto $\mathrm{PGF}_{1 \alpha}$, the stable hydrolysis product of $\mathrm{PGI}_{2}$. The cells were then immediately extracted with $0.6 \mathrm{ml}$ of ice cold TCA (6\%) and scraped off with a rubber policemant. The cell suspension was then sonicated for 10 $s$ before being centrifuged for $5 \mathrm{~min}$ at $4,000 \mathrm{~g}$. Supernatants were extracted with $4 \mathrm{vol}$ of water-saturated diethylether, and the samples were kept frozen $\left(-20^{\circ} \mathrm{C}\right)$ until analysis. Cyclic GMP was determined in the acetylated samples using a commercially available radioimmunoassay (New England Nuclear, Dreieich, Germany). Cyclic GMP content was expressed as picomoles cyclic GMP per milligram protein.

Immunostaining of cultured cells for renin. For the immunodemonstration of renin the cells were grown on multichamber slides. The culture medium was carefully removed and the cells were fixed for 10 min with $2.5 \%$ paraformaldehyde (freshly prepared) and $0.1 \%$ glutaraldehyde, diluted in PBS supplemented with $3 \mathrm{mM} \mathrm{MgCl}_{2}$ and $0.05 \%$ picric acid. The fixed cells were then washed for $15 \mathrm{~min}$ in PBS- $\mathrm{NH}_{4} \mathrm{Cl}$ ( $50 \mathrm{mM}$ ), to quench residual aldehyde groups. Thereafter the cells were permeabilized in PBS-saponin buffer (PBS, $0.55 \mathrm{M} \mathrm{NaCl}, 0.1 \mathrm{M}$ glycin, $0.1 \%$ saponin, and $1 \% \mathrm{BSA}, \mathrm{pH} 7.2$ ) twice for $5 \mathrm{~min}$.

The cells were preincubated with normal goat serum (Dakopatts, Glostrup, Denmark) in the PBS-saponin buffer for $10 \mathrm{~min}$, and incubated for $60 \mathrm{~min}$ with the primary antibody against mouse renin (gift of Prof. Corvol, Paris), which had been raised in rats. The rat serum was diluted 1:500 in PBS-saponin.

After two rinses in PBS-saponin, primary antibody-binding to the cells was visualized with goat-anti-rat-FITC (fluoresceinisothiocyanate; Jackson Immuno Research Laboratories Inc., Avondale, PA), diluted 1:100 in PBS saponin. The secondary antibody was preadsorbed with normal mouse serum $(10 \mu \mathrm{l} / \mathrm{ml}$ goat anti-rat serum) for $10 \mathrm{~min}$ 
and centrifuged for $1 \mathrm{~min}$ at $10,000 \mathrm{rpm}$ before use, in order to prevent unspecific binding of the second antibody to mouse cells. For nuclear staining $2 \mu \mathrm{g} / \mathrm{ml}$ DAPI (4'-6'diamidino-2-phenylindol; Boehringer Mannheim GmbH, Mannheim, Germany) were added to the secondary antibody.

After two rinses, each $5 \mathrm{~min}$, in PBS the cells were counterstained for 3 min with Evan's blue (E. Merck, Darmstadt, Germany), $1 \%$ in water, and rinsed briefly in water. The chambers were disabled and the slides were covered with coverslips using glycergel (Dakopatts, Glostrup, Denmark), added with $25 \mathrm{~g} /$ liter DABCO (Diazabiciclo [2.2.2] octane; Sigma Chemical Co., St. Louis, MO) as fading retardant. The following controls were made to test the specificity of the binding: (a) the antiserum against mouse renin was replaced by normal rat serum at the same concentration; $(b)$ serum was omitted and replaced by PBS; (c) the antiserum against renin was tested in addition on tissue sections of rat kidney, fixed in a similar way as the cultured cells. There specific fluorescence was limited to globular granules situated in the layer of smooth muscle cells of afferent arterioles.

The preparations were examined with a Polyvar microscope (Reichert, Vienna, Austria) by differential interference contrast (DIC, Nomarski optics) and by epifluorescence, using filters for FITC (excitation filter band pass, $330-380 \mathrm{~nm}$ ), revealing the nuclear staining. Micrographs were made using Kodak T-max 400, professional film, TMY 135 (Kodak Ltd., Hemel Hampstead, England).

Measurement of protein. Protein concentration in cellular extracts were determined with a commercially available protein assay (Bio-Rad Laboratories, Glattbrugg, Switzerland) using BSA as a standard.

Materials. $N^{\mathrm{G}}$-Nitro-L-arginine, superoxide dismutase (bovine erythrocytes, sp act 3,300 U/mg) were purchased from Serva (Heidelberg, FRG). $N^{\mathrm{G}}$-Monomethyl-l-arginine, ATP, indomethacin, nordihydroguiaretic acid, endothelin, and isoproterenol were from Sigma Chemical Co. Forskolin and fura-2AM were obtained from Calbiochem-Behring Corp. (San Diego, CA).

Statistics. Levels of significance were calculated utilizing an un, paired $t$ test. $P<0.05$ was considered significant.

\section{Results}

Because previous studies have shown that the content of inactive renin in the mouse renal cell cultures highly enriched in juxtaglomerular cells is $<10 \%$ of absolute renin activity (11), only primarily active renin was considered in this study. Total renin activity after lysis of the primary renal cell cultures after $48 \mathrm{~h}$ of culture was $3.2 \pm 0.3 \mu \mathrm{g}$ ANG I/h per $100 \mu \mathrm{g}$ cellular protein (mean \pm SEM; $n=9$ ). This corresponded to $557 \pm 85 \mathrm{ng}$ ANG $\mathrm{I} / \mathrm{h}$ per culture well (nine experiments). In the presence of endothelial cells (EC) total renin activity was significantly $(P$ $<0.05$ ) increased to $869 \pm 140 \mathrm{ng}$ ANG I/h per culture well, when renal cells were seeded at the same number in the absence and the presence of EC.

Specific renin immunoreactivity was found in spherical cells, ranging between 6 and $8 \mu \mathrm{m}$ in diameter, which were densely stuffed with globular granules of varying size (Fig. 1). The very bright specific fluorescence, indicating the presence of renin, was confined to these granules. Groups or single renincontaining cells were most often attached to endothelial cells (Fig. 1). The latter were recognized by observation with DIC on account of their typical flat elongated cell body, which extended into long narrow processes at both extremities. EC were totally negative for renin as found by immunostaining against renin and by analysis of intracellular renin activity. Endothelial cells favored the attachment of renin negative cells, too. As a consequence the percentage of renin-positive cells decreased from $40-70 \%$ in the absence of $E C$ to $20-30 \%$ in the presence of EC.

Because it was the aim of this study to make quantitative comparisons of renin secretion rates between the absence and the presence of EC, and because total cellular mass and total renin activity were different between both culture conditions, we used the fractional renin release (i.e., renin released/[renin released + renin remaining in the cells]) as a comparable parameter for the cocultures. To ensure that fractional renin release was in fact independent on total cell mass and total renin activity, fractional renin release was measured as a function of total renin activity, which was varied by seeding the renal cells at different densities. As shown in Fig. 2, both spontaneous and forskolin-stimulated fractional renin release were independent on total renin activity. The same behavior was also found for the cocultures with EC (not shown). We then examined whether EC exerted a basal influence on spontaneous and stim-

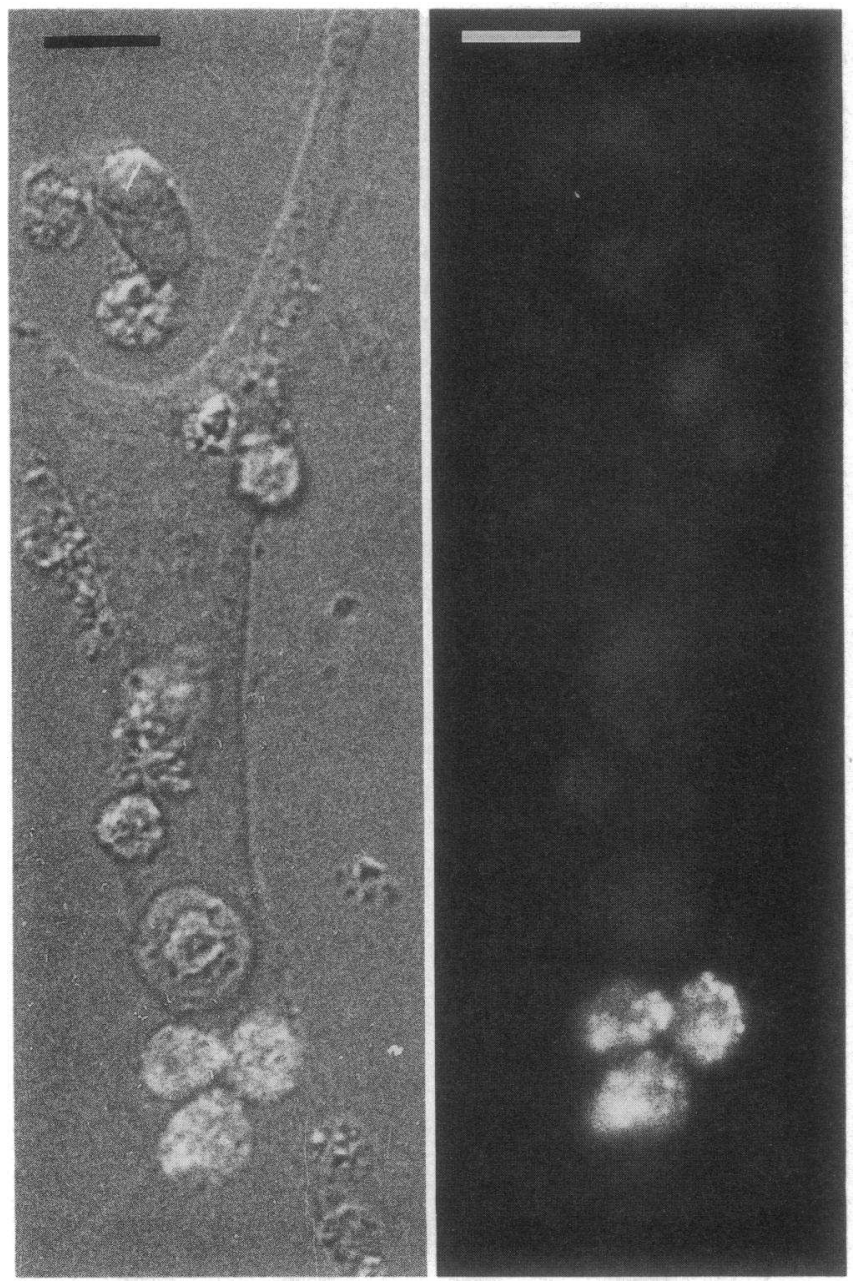

Figure 1. Differential interference contrast photomicrograph $(l e f t)$ and indirect immunofluorescence staining against mouse renin (right) of cocultures of bovine microvascular endothelial cells with mouse renal cells enriched with JG cells. Note the flat endothelial cell in the center to which rounded renal cells have attached. Also note the bright granular fluorescence staining of three JG cells at the upper corner of the endothelial cell. Bars, $10 \mu \mathrm{m}$. 


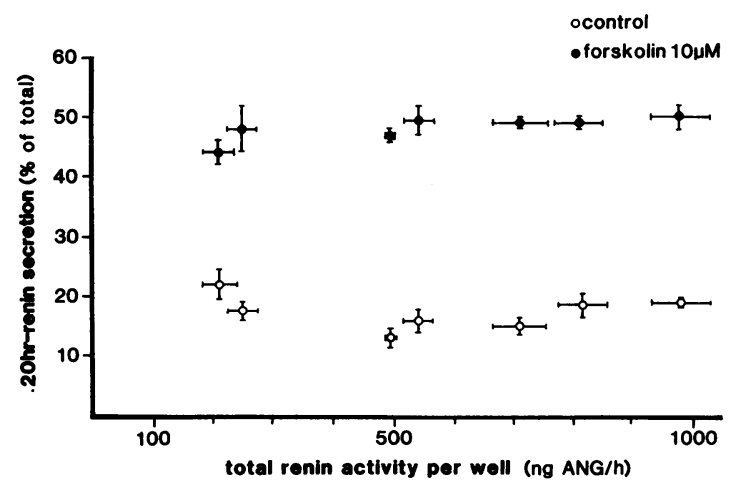

Figure 2. Fractional renin release from cultured mouse JG cells in relation to the total renin activity per culture. Data are shown for basal and for forskolin $(10 \mu \mathrm{M})$ stimulated secretion. Values are means \pm SEM of six culture wells each.

ulated renin secretion. Stimulation of renin secretion was achieved along three different pathways, namely via adenylate cyclase stimulation by forskolin $(10 \mu \mathrm{M})$ and isoproterenol (10 $\mu \mathrm{M})(4)$, via inhibition of calmodulin activity by calmidazolium $(10 \mu \mathrm{M})(4)$ and via inhibition of sodium-proton exchange by ethylisopropylamiloride ( 10 and $50 \mu \mathrm{M})$ and by $\mathrm{NH}_{4} \mathrm{Cl}$ (18). As shown in Fig. 3 the presence of EC significantly attenuated spontaneous, forskolin, and isoproterenol-stimulated renin secretion. EC on the other hand did not alter stimulation of renin secretion by the calmodulin antagonist. Stimulation of renin secretion by the amiloride derivative and by $\mathrm{NH}_{4} \mathrm{Cl}$ was even enhanced in presence of EC (Fig. 4).

To find possible reasons for the inhibitory influence of EC on basal and CAMP-stimulated renin secretion, the effect of EC-conditioned medium on renin release was tested in the absence of EC. However, culture medium conditioned by EC for

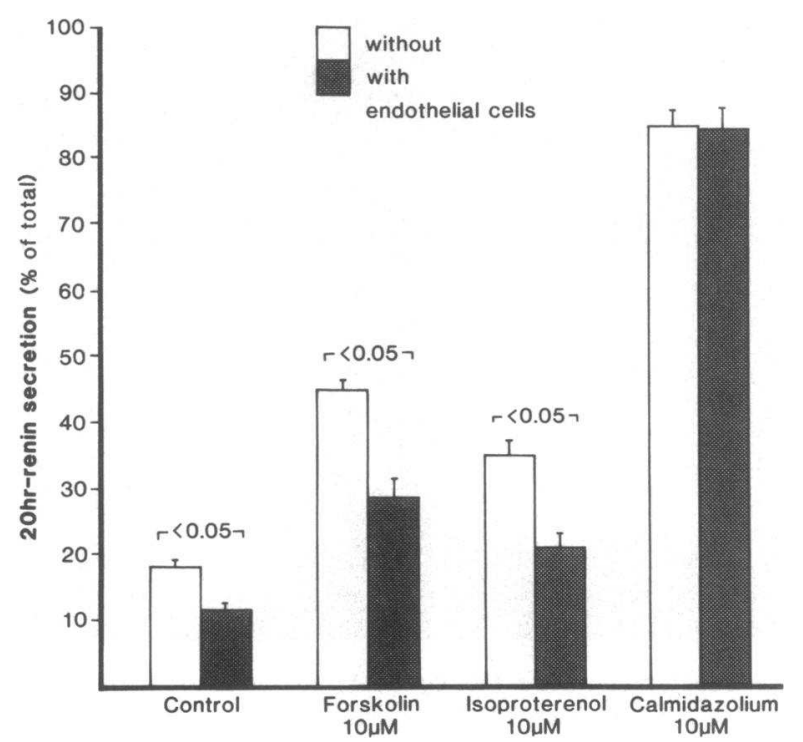

Figure 3. Renin release from mouse JG cells stimulated by forskolin, isoproterenol, and calmidazolium (all at $10 \mu \mathrm{M}$ ) in the absence and in the presence of endothelial cells. Data are means \pm SEM of four experiments, each representing the mean of six replicate culture wells.

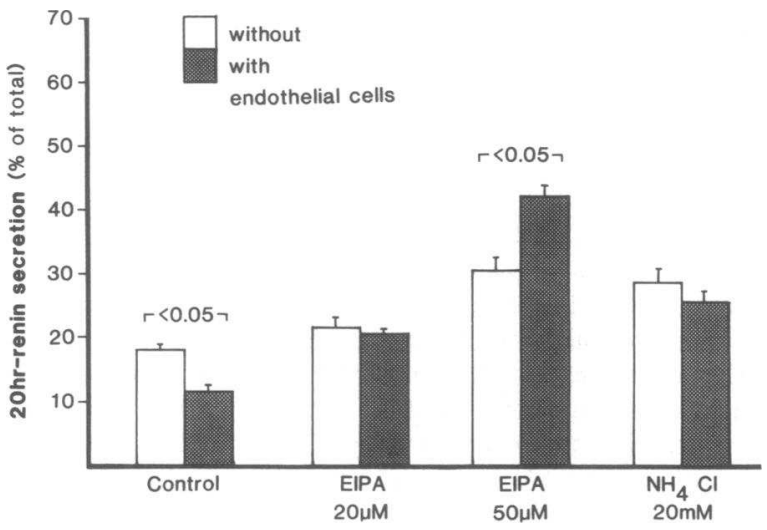

Figure 4. Renin release from mouse juxtaglomerular cells stimulated by ethylisopropylamiloride (EIPA) or by ammonium-chloride in the absence and in the presence of endothelial cells. Data are means \pm SEM of four experiments, each being the mean of six replicate culture wells. Renin secretion both in the absence and in the presence of endothelial cells was significantly increased by ammonium-chloride $(P<0.05$ vs. control).

$20 \mathrm{~h}$ in the absence and in the presence of $10 \mu \mathrm{M}$ forskolin had no inhibitory effect on renin secretion, whereas forskolin was fully active even after $20 \mathrm{~h}$ preincubation with EC (not shown). We then examined whether the inhibitory effect on renin secretion was specific for EC at all and we therefore compared the effects of EC with that of a human hepatoma cell line (Hep G2) which are not expected to make a specific physiologic interaction with JG cells. As shown in Table I was total renin activity in cocultures with Hep G2 cells increased to the same extent as in cocultures with EC. Moreover, also spontaneous renin release was reduced to a degree seen with EC. Forskolin-stimulated renin secretion, however, was attenuated in the presence of EC only. To see whether the inhibitory effect of EC on renin secretion was related to adenylate cyclase activation or more generally to cAMP stimulated renin secretion we furthermore examined the effects of 8-bromo-cAMP (10 mM), isobutylmethylxanthine (IBMX, $0.5 \mathrm{mM}$ ), which is an inhibitor of cAMP-phosphodiesterase and of pertussis toxin $(100 \mathrm{ng} / \mathrm{ml})$ which inactivates the inhibitory subunit of adenylate cyclase (19), on renin secretion in the absence and in the presence of

Table I. Total Renin Activity and Basal and Forskolin-stimulated Renin Secretion in Cocultures of Mouse Renal Juxtaglomerular Cells with Bovine Microvascular Endothelial Cells and with Human Hepatoma (Hep-G2) Cells

\begin{tabular}{lccc}
\hline & $\begin{array}{c}\text { Total renin } \\
\text { activity }\end{array}$ & $\begin{array}{c}\text { Basal renin } \\
\text { release }\end{array}$ & $\begin{array}{c}\text { Forksolin }(10 \mu \mathrm{M}) \\
\text { stimulated renin release }\end{array}$ \\
\hline & $n g A I / h x$ well & \% of total & \% of total \\
JG cells alone & $540 \pm 25$ & $15.8 \pm 2.1$ & $49.6 \pm 2.9$ \\
$\begin{array}{l}\text { With endothelial } \\
\text { cells }\end{array}$ & & & \\
With Hep-G2 cells & $640 \pm 27^{*}$ & $10.6 \pm 1.9^{*}$ & $37.0 \pm 2.1^{*}$ \\
& $691 \pm 19^{*}$ & $9.73 \pm 0.8^{*}$ & $45.4 \pm 1.5$ \\
\hline
\end{tabular}

Data are means \pm SEM of six replicate culture wells each. ${ }^{*} P<0.05$ vs. respective controls. 


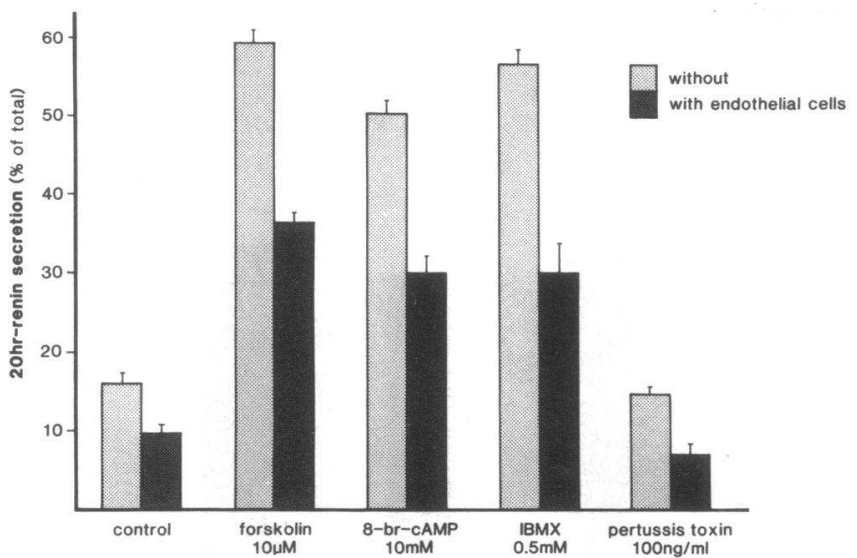

Figure 5. Effects of forskolin $(10 \mu \mathrm{M}), 8$-bromo-cyclic AMP (10 mM), isotuylmethylxanthine (IBMX, $0.5 \mathrm{mM}$ ) and pertussis toxin (100 ng/ $\mathrm{ml}$ ) on $20 \mathrm{~h}$ renin secretion from isolated mouse juxtaglomerular cells in the absence and in the presence of endothelial cells.

EC (Fig. 5). With the exception of pertussis toxin, these drugs stimulated renin secretion in a similar fashion as did forskolin (Fig. 5). In presence of EC renin secretion enhanced by 8bromo-cAMP and by IBMX was attenuated to the same degree as forskolin stimulated renin release (Fig. 5).

To examine whether this inhibitory effect of EC on cAMPstimulated renin secretion was mediated by endothelial autacoids such as cyclooxygenase and lipoxygenase products or EDRF (5) we used indomethacin $(10 \mu \mathrm{M})$ to block cyclooxygenase activity (20), nordihydroguiaretic acid (NDGA, $50 \mu \mathrm{M}$ ) to inhibit lipoxygenases (20) and $N^{\mathrm{G}}$-monomethylarginine (NMMA, $1 \mathrm{mM}$ ) to attenuate EDRF formation (21). As shown

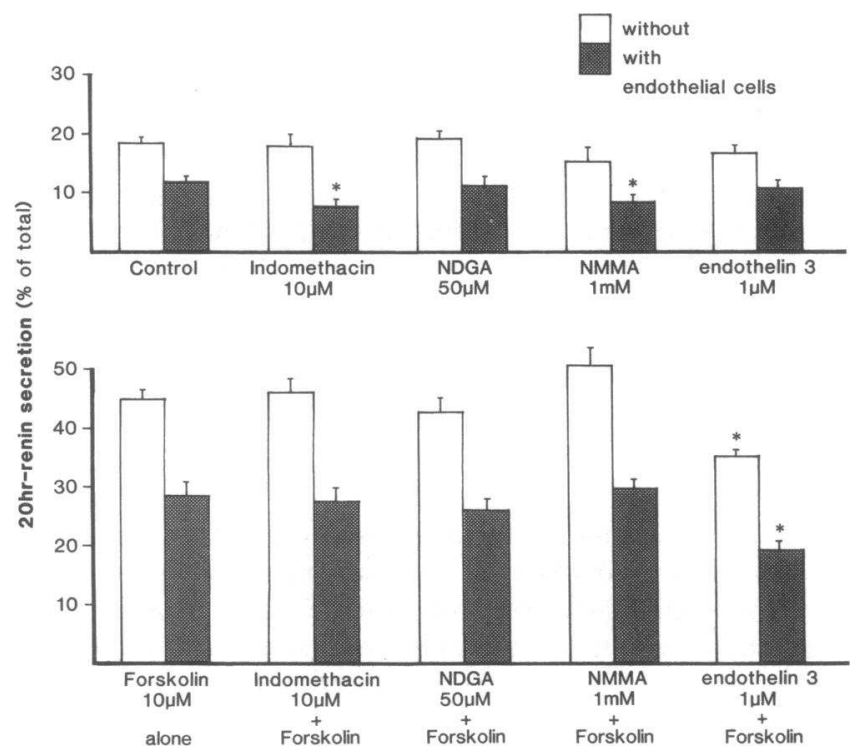

Figure 6. Effects of indomethacin, nordihydroguiaretic acid (NDGA), $N^{\mathrm{G}}$-monomethylarginine (NMMA) and endothelin-3 on basal (top) and on forskolin $(10 \mu \mathrm{M})$ stimulated renin release (bottom) from mouse juxtaglomerular cells in the absence and in the presence of endothelial cells. Data are means \pm SEM of three experiments, each being the mean of six replicate culture wells.

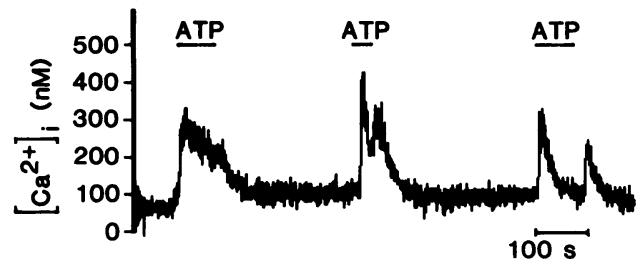

Figure 7. Intracellular calcium concentration in a single bovine microvascular endothelial cells after replicate application of ATP (10 $\mu \mathrm{M})$.

in Fig. 6 among these drugs indomethacin and NMMA were active in way that they further decreased spontaneous renin release in the presence of EC. NDGA had no effect on spontaneous nor on forskolin-stimulated renin release in the absence and in the presence of EC (Fig. 6). The strongest effect of endothelial autacoids as examined in this study was exerted by endothelin which inhibited forskolin-stimulated renin secretion in the absence and in the presence of EC (Fig. 6).

Finally, we were interested to see how renin secretion from isolated JG cells is influenced by endothelial cells if both cell types are simultaneously activated. For these experiments we used ATP $(10 \mu \mathrm{M})$ which acts on VSMC and on EC through phospholipase $C$ activation mediated via purinergic $P_{2}$ receptors $(22,23)$. The existence of $P_{2}$ receptors linked to phospholipase $C$ in the capillary endothelial cell used in this study is strongly suggested by the calcium mobilizing effect of ATP (10 $\mu \mathrm{M})$ in the cells (Fig. 7). ATP $(10 \mu \mathrm{M})$ also caused the release of prostacyclin (Fig. 8). ATP, moreover, enhanced the release of a factor capable to activate soluble guanylate cyclase activity (Fig. 8) and to raise intracellular cGMP levels in the EC (Table II). Because the production of this factor was inhibited by $N^{\mathrm{G}}$ nitro- $l$-arginine (Fig. 8) it appears reasonable to assume that this factor stimulated by ATP was EDRF which is considered to be nitric oxide (24).

In the JG cells ATP $(10 \mu \mathrm{M})$ led to a significant suppression of forskolin and isoproterenol-stimulated renin secretion in the absence of EC (Fig. 9, top). In the presence of endothelial cells, however, ATP had lost its inhibitory effect on renin secretion
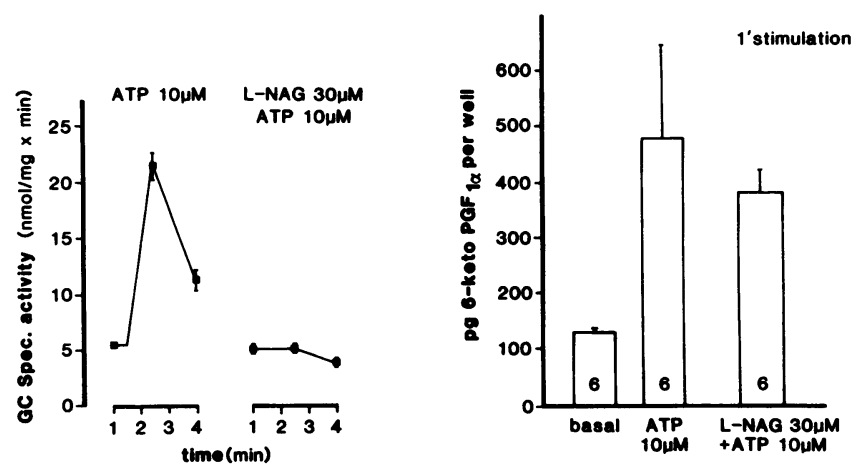

Figure 8. Stimulation of release of EDRF (left) and prostacyclin (right) by ATP $(10 \mu \mathrm{M})$ from cultured bovine microvascular endothelial cells. Note that stimulation of EDRF release but not of prostacyclin release is inhibited by $N^{\mathrm{G}}$-nitro-l-arginine (L-NAG). Data are means \pm SEM of five replicate cultures each. The details of the assays are described in Methods. 
Table II. Intracellular Levels of Cyclic GMP in Cultures of Bovine Microvascular Endothelial Cells after Stimulation with ATP

\begin{tabular}{lc}
\hline & CGMP \\
\hline & pmol/mg protein \\
Control & $1.7 \pm 0.3$ \\
ATP $(10 \mu \mathrm{M})$ & $3.9 \pm 0.8^{*}$ \\
ATP $(10 \mu \mathrm{M}) / l$-NAG $(30 \mu \mathrm{M})$ & $1.9 \pm 0.4$ \\
\hline
\end{tabular}

$N^{\mathrm{G}}$-Nitro-l-arginine ( $l$-NAG) was preincubated for $5 \mathrm{~min}$ before addition of ATP. cGMP samples were taken $150 \mathrm{~s}$ after the addition of ATP. Data are means \pm SEM of six cultures each. ${ }^{*} P<0.05$ vs. control.

(Fig. 9, bottom). This countercurring effect of EC was not altered by indomethacin $(10 \mu \mathrm{M})$ nor by NMMA $(1 \mathrm{mM})$ (Fig. 10 ), which were used to inhibit prostacyclin and EDRF formation.

\section{Discussion}

It was the aim of this study to examine whether endothelial cells can exert direct influence on renin secretion from renal JG cells. Our findings show that capillary EC markedly influenced the secretory behavior of isolated JG cells during $20 \mathrm{~h}$ of coculture. In the presence of EC, both spontaneous and cAMPstimulated renin secretion were attenuated (Figs. 3 and 5). EC did not generally inhibit renin secretion as indicated by the findings that stimulation of renin secretion by calmodulin antagonists was not altered, whereas the stimulatory effect of pu-

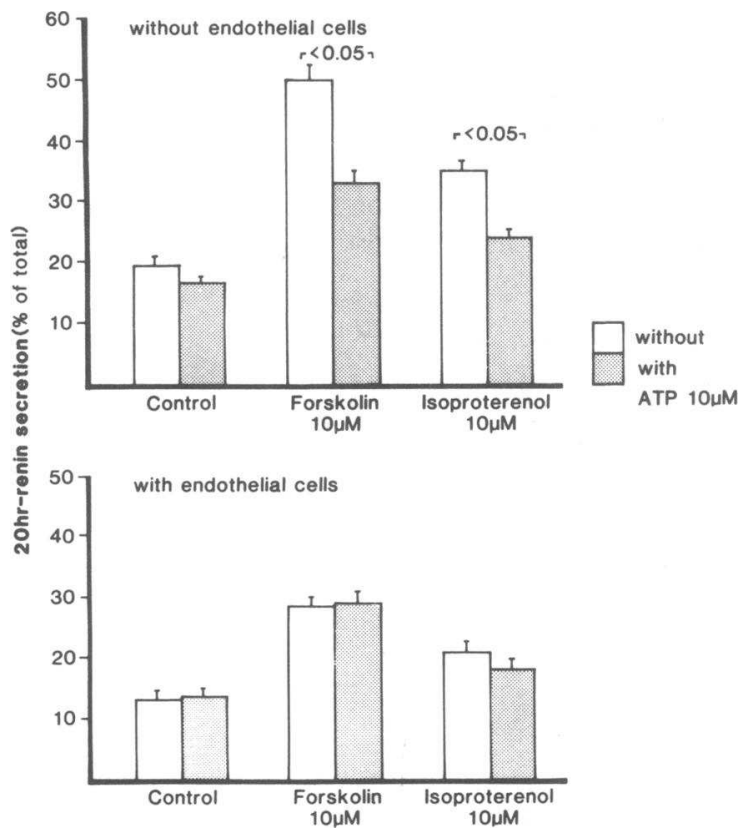

Figure 9. Effect of ATP $(10 \mathrm{M})$ on basal and forskolin or isoproterenol-stimulated renin release from mouse JG cells in the absence (top) and in the presence of endothelial cells (bottom). Data are means \pm SEM of four experiments, each being the mean of six replicate culture wells.

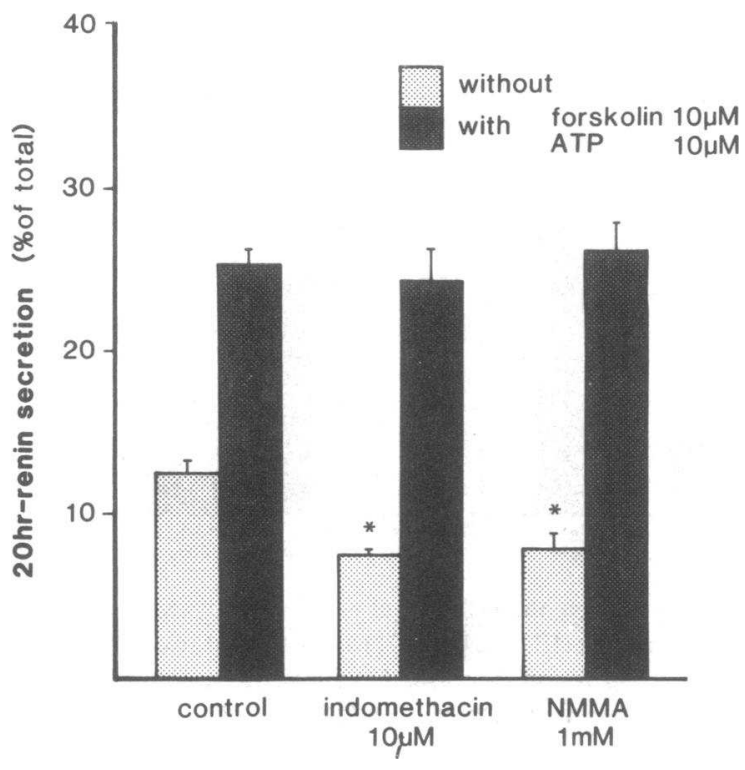

Figure 10. Effects of indomethacin $(10 \mu \mathrm{M})$ and of NMMA (1 mM) on renin release from cocultures of endothelial and juxtaglomerular cells in the absence and in the presence of forskolin $(10 \mu \mathrm{M})$ plus ATP $(10 \mu \mathrm{M})$. Data are means \pm SEM of six replicate cultures each

tative inhibitors of sodium proton exchange was even enhanced in the presence of EC (Fig. 4). The observation that the inhibitory effect of EC was not mimicked by endothelial cell conditioned medium suggests that it was mediated either by structural alterations of JG cells due to attachment to EC or was mediated by factors which required higher local concentrations or which had a weak stability. Structural changes of JG cells due to attachment to other cells may indeed play a role, because spontaneous renin release was also decreased in the presence of human hepatoma cells (Table I), which are not expected to specifically interact with JG cells. The inhibitory effect of EC on cAMP stimulated renin secretion, on the other hand, appears to be more specific for EC. Because EC produce several autacoids, such as cyclooxygenase and lipoxygenase products, EDRF and endothelin (1), which all have been found in short-term experiments to influence renin secretion in vitro (5), we examined a possible involvement of those factors in the action of EC on JG cells. Inhibition of cyclooxygenase by indomethacin during $20 \mathrm{~h}$ significantly decreased spontaneous renin release in the presence of EC only, but not cAMP-stimulated renin secretion (Fig. 6). This observation fits with a number of findings that cyclooxygenase inhibition also leads an acute to attenuation of renin release from preparations with intact endothelium (5). A good candidate for such a stimulatory endothelial factor resulting from cyclooxygenase activity is prostacyclin which is the major cyclooxygenase product of arachidonic acid in EC (25) and which is known as a potent stimulator of renin secretion (4). One could speculate therefore from our long-term experiments that endothelial derived $\mathrm{PGI}_{2}$ exerts not only an acute but also a tonical stimulatory influence on JG cells. PGI $_{2}$ increases renin secretion via cAMP formation (26) and this may be the explanation why indomethacin did not attenuate forskolin-induced renin secretion in the presence of EC (Fig. 6). In the presence of $10 \mu \mathrm{M}$ forskolin cAMP 
levels in JG cells are expected to be strongly increased (27) and a possible additional contribution of $\mathrm{PGI}_{2}$ to cAMP levels is therefore probably small. Also EDRF could be a possible endothelial modulator of renin secretion, because EDRF has been suggested to cause an acute inhibition of renin secretion in vitro (6). Our findings show that prolonged exposure of JG-EC cocultures with the inhibitor of EDRF formation NMMA also causes attenuation of spontaneous renin secretion. Whether these seemingly contrary findings are due to the markedly different times of incubation or to the different experimental models used remains to be clarified. In any case, it is unlikely that the inhibitory effect of EC on renin secretion as seen in this study (Fig. 6) was mediated by EDRF.

Lipoxygenase products appeared to be not involved in the basal influence of EC on renin secretion from JG cells, because the lipoxygenase inhibitor NDGA had no effect on spontaneous or CAMP stimulated renin secretion (Fig. 6). At higher concentrations $(500 \mu \mathrm{M})$ NDGA turned out to be toxic as indicated by a marked fall of total renin activity in the cultures (not shown). The only endothelial autacoid investigated in this study that was clearly inhibitory for renin secretion was endothelin (Fig. 6). This finding thus supports recent findings that endothelin inhibits renin secretion from renal slices (7, $10)$, isolated glomeruli (9), and superfused renal cortical cells (8), and isolated rat JG cells (10). Thus, endothelin could be a modulatory signal released by EC, attenuating cAMP-induced renin secretion.

A separate set of experiments was performed to examine the situation if JG cells and endothelial cells are simultaneously activated by the same factor. For these experiments we used ATP which is thought to be secreted from sympathetic nerve endings (28), which in turn exist at high density in the JG region (2). The existence of purinergic ATP $\left(P_{2}\right)$ receptors linked to phospholipase C (PLC) on JG cells is strongly suggested by the observation that ATP leads to depolarization of JG cells in a fashion typical for hormones activating PLC (29). The existence of $P_{2}$ receptors linked to PLC and activated by ATP is also likely for endothelial cells. Thus activation of $\mathbf{P}_{\mathbf{2}}$ receptors by ATP leads stimulation of phospholipid turnover (23) to calcium mobilization and release of EDRF and $\mathrm{PGI}_{2}$ in $\operatorname{EC}(23,30)$, effects that were also seen in this study (Figs. 7 and 8). It turned out that ATP-inhibited renin secretion from JG cells in the absence of EC as it would be expected for a factor activating PLC (Fig. 9) (26). In the presence of EC, however, ATP had lost its inhibitory effect of renin secretion (Fig. 9). Because this neutralizing effect of EC was not altered by inhibition of cyclooxygenase activity nor by inhibition of EDRF formation (Fig. 10) it is reasonable to assume that it was not mediated by prostacyclin nor by EDRF. In consequence, the mechanism by which EC neutralize the direct inhibitory effect of ATP on JG cells remains to be clarified. A possible mediator could be endothelium-derived hyperpolarizing factor which is produced by EC in response to ATP (31) and which is thought to open (ATP-sensitive) potassium channels in VSMC (32). This idea would fit with the observation that the potassium channel opener cromakalim exerts a stimulatory effect on renin secretion from isolated rat JG cells (33).

Taken together, our findings indicate that renin secretion from renal JG cells is significantly influenced by the endothelial cells. They suggest that cAMP stimulated renin secretion is rather specifically attenuated by EC, and furthermore, they provide evidence that $\mathrm{PGI}_{2}, \mathrm{EDRF}$ and endothelin may be oppositely acting autacoids mediating a tonical influence of the endothelium on JG cells. The obtained results also provide first evidence that the endothelium could be an important modulator of renin secretion controlled by sympathetic nerve activity.

Further experiments will be necessary to elucidate the role of the endothelium in the control of renin secretion in more detail and we think that cocultures of capillary EC with isolated JG cells could be a suitable model to perform those experiments.

\section{Acknowledgments}

We are indebted to Dr. Montesano for providing us with BME and to Dr. Corvol for the generous gift of antiserum against mouse renin. We gratefully acknowledge the artwork done by Christian Gasser and the secretarial help provided by Hannelore Trommer.

This study was financially supported by grants of the Swiss National Science Foundation (grant 31-26381.89), of the Sandoz Stiftung, Roche Foundation, and of the Hartmann-Müller Stiftung.

\section{References}

1. Furchgott, R. F., and P. M. Vanhoutte. 1989. Endothelium-derived relaxing and contracting factors. FASEB (Fed. Am. Soc. Exp. Biol.) J. 3:2007-2018.

2. Barajas, L. 1979. Anatomy of the juxtaglomerular apparatus. Am. J. Physiol. 236:F333-F343.

3. Taugner, R., C. P. Bührle, E. Hackenthal, E. Mannek, and R. Nobiling. 1984. Morphology of the juxtaglomerular apparatus and secretory mechanisms. Contrib. Nephrol. 43:76-101.

4. Hackenthal, E., M. Paul, D. Ganten, and R. Taugner. 1990. Morphology, physiology, and molecular biology of renin secretion. Physiol. Rev. 70:10671116.

5. Campbell, W. B., and W. L. Henrich. 1990. Endothelial factors in the regulation of renin release. Kidney Int. 38:612-617.

6. Vidal, M. J., J. C. Romero, and P. M. Vanhoutte. 1988. Endothelium-derived relaxing factor inhibits renin release. Eur. J. Pharmacol. 149:401-402.

7. Matsumura, Y., K. Nakase, K., R. Ikegawa, K. Hayshi, T. Ohyama, and S. H. Morimoto. 1989. The endothelium-derived vasoconstrictor peptide endothelin inhibits renin release in vitro. Life Sci. 44:149-157.

8. Takagi, M., H. Matsuoka, K. Atarashi, and S. Yagi. 1988. Endothelin: a new inhibitor of renin release. Biochem. Biophys. Res. Commun. 157:11641167.

9. Rakugi, H., M. Nakamaru, H. Saito, J. Higaki, and T. Ogihara. 1988. Endothelin inhibits renin release from isolated rat glomeruli. Biochem. Biophys. Res. Commun. 155:1244-1247.

10. Moe, O., A. Tejedor, W. B. Campbell, R. J. Alpern, and W. L. Henrich. 1991. Effects of endothelin on in vitro renin secretion. Am. J. Physiol. E521E525.

11. Della Bruna, R., F. Pinet, P. Corvol, and A. Kurtz. 1991. Regulation of renin secretion and renin synthesis by second messengers in isolated mouse juxtaglomerular cells. Cell. Physiol. Biochem. 1:98-110.

12. Furie, M. B., E. B. Cramer, B. L. Naprstek, and S. M. Silverstein. 1984. Cultured endothelial cells monolayers that restrict the transendothelial passage of macromolecules and electrical currents. J. Cell Biol. 98:1033-1041.

13. Kurtz, A., J. Pfeilschifter, A. Hutter, C. P. Buhrle, R. Nobiling, R. Taugner, E. Hackenthal, and C. Bauer. 1986. Role of protein kinase C in vasoconstrictor caused inhibition of renin release from isolated juxtaglomerular cells. Am. J. Physiol. 250:C563-C571.

14. Neher, E. 1988. The influence of intracellular calcium concentration on degranulation of dialysed mast cells from rat peritoneum. J. Physiol. (Lond.). 295:193-214.

15. Grynkiewicz, G., M. Poenie, and R. Y. Tsien. 1985. A new generation of $\mathrm{Ca}^{2+}$ indicators with greatly improved fluorescence properties. J. Biol. Chem. 260:3440-3450.

16. Kurtz, A., and R. Penner. 1989. Angiotensin II induces oscillations of intracellular calcium and blocks anomalous inward rectifying potassium current in mouse renal juxtaglomerular cells. Proc. Natl. Acad. Sci. USA. 86:3423-3427.

17. Mülsch, A., E. Böhme, and R. Busse. 1987. Stimulation of soluble guanylate cyclase by endothelium-derived relaxing factor from cultured endothelial cells. Eur. J. Pharmacol. 135:247-250. 
18. Kurtz, A., R. Della Bruna, H. Scholz, and W. Baier. 1991. Amiloride enhances the secretion but not the synthesis of renin in renal juxtaglomerular cells. Eur. J. Physiol. In press.

19. Murayama, T., and M. Ui. 1983. Loss of the inhibitory function of the guanine nucleotide regulatory component of adenylate cyclase is due to its ADP ribosylation by islet activating protein, pertussis toxin, in adipocyte membranes. J. Biol. Chem. 258:3319-3326.

20. Needleman, P., J. Turk, B. A. Jakschik, A. R. Morrison, and J. B. Lefkowith. 1986. Arachidonic acid metabolism. Annu. Rev. Biochem. 55:69-102.

21. Palmer, R. M. J., D. D. Rees, D. S. Ashton, and S. Moncada. 1988 L-Arginine is the physiological precursor for the formation of nitric oxide in endothelium-dependent relaxation. Biochem. Biophys. Res. Commun. 3:12511256.

22. Phaneuf, S., P. Berta, J. Casanova, and J.-C. Cavadore. 1987. ATP stimulates inositol phosphates accumulation and calcium mobilization in a primary culture of rat aortic myocytes. Biochem. Biophys. Res. Commun. 143:454-460.

23. Forsberg, E. J., G. Feuerstein, E. Shohami, and H. B. Pollard. 1987. Adenosine triphosphate stimulates inositol phospholipid metabolism and prostacyclin formation in adrenal medullary endothelial cells by means of $P_{2}$-purinergic receptors. Proc. Natl. Acad. Sci. USA. 84:5630-5634.

24. Palmer, R. M. J., A. G. Ferrige, and S. Moncada. 1987. Nitric oxide release accounts for the biological activity of endothelium-derived relaxing factor. Nature (Lond.). 327:524-526.

25. Satoh, H., and S. Satoh. 1984. Prostaglandin $E_{2}$ and $I_{2}$ production in isolated dog renal arteries in the absence or presence of vascular endothelial cells. Biochem. Biophys. Res. Commun. 118:873-876.

26. Kurtz, A. 1989. Cellular control of renin secretion. Rev. Physiol. Biochem. Pharmacol. 113:1-40.

27. Kurtz, A., J. Pfeilschifter, and C. Bauer. 1984. Is renin secretion governed by the calcium permeability of the juxtaglomerular cell membrane? Biochem. Biophys. Res. Commun. 124:359-366.

28. Burnstock, G. 1981. Neurotransmitters and trophic factors in the autonomic nervous system. J. Physiol. (Lond.). 313:1-35.

29. Bührle, C. P., H. Scholz, E. Hackenthal, R. Nobiling, and R. Taugner. 1986. Epithelioid cells: membrane potential changes induced by substances influencing renin secretion. Mol. Cell. Endocrinol. 45:37-47.

30. Lückhoff, A., and R. Busse. 1990. Calcium influx into endothelial cells and formation of endothelium-derived relaxing factor is controlled by the membrane potential. Pfluegers Arch. Eur. J. Physiol. 416:305-311.

31. Chen, G., and H. Suzuki. 1991. Endothelium-dependent hyperpolarization elicited by adenine compounds in rabbit carotid artery. Am. J. Physiol. 260:H1037-H1042.

32. Standen, N. B., J. M. Quayle, N. W. Davies, J. E. Byayden, Y. Huang, and M. T. Nelson. 1989. Hyperpolarizing vasodilators activate ATP-sensitive $\mathrm{K}^{+}$channels in arterial smooth muscle. Science (Wash. DC). 245:177-180.

33. Ferrier, C. P., A. Kurtz, P. Lehner, S. G. Shaw, C. Pusterla, H. Saxenhofer, and $P$. Weidmann. 1989. Stimulation of renin secretion by potassium-channe activation with cromakalim. Eur. J. Clin. Pharmacol. 36:443-447. 